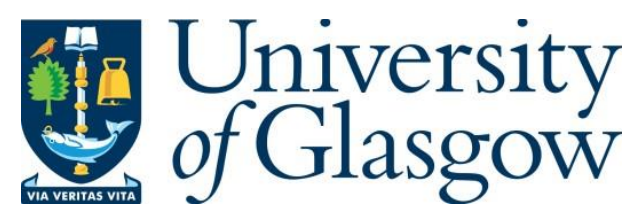

Aliyev, H. (2015) Informal networks as sources of human (in)security in the South Caucasus. Global Change, Peace and Security, 27(2), pp. 191-206.

There may be differences between this version and the published version. You are advised to consult the publisher's version if you wish to cite from it.

http://eprints.gla.ac.uk/153382/

Deposited on: 11 December 2017

Enlighten - Research publications by members of the University of Glasgow http://eprints.gla.ac.uk 


\title{
Informal networks as sources of human (in)security in the South Caucasus
}

\author{
Huseyn Aliyev ${ }^{1}$ \\ Research Centre for East European Studies (Forschungsstelle Osteuropa), University of \\ Bremen, Bremen, Germany
}

Received 24 September 2014; accepted

In contrast to numerous studies on exogenous mechanisms of human securitysuch as the provision of human security by international actors - this study examines the role of informal networks in providing 'freedoms from want' and 'freedoms from fear' to the population. With the primary focus post-communist South Caucasus (Armenia, Azerbaijan and Georgia) this article conducts a rigorous examination of informal networks' critical function as sources of human (in)security since the break up of the Soviet Union. Based on a combination of open-ended elite (expert) interviews, field observation and close-ended survey data, this study demonstrates that apart from the informal networks' crucial role in generating social capital and functioning as indispensable social safety nets, they also exacerbate human insecurity by cementing the deeply-entrenched in the region traditions of clientelism and corruption.

Keywords: South Caucasus; informal networking; human security; 'freedom from fear'; 'freedom from want'

\footnotetext{
${ }^{1}$ Email: p04alh01@yahoo.com.
} 


\section{Introduction}

The contemporary South Caucasus_-including the republics of Armenia, Azerbaijan and Georgia - is rife with challenges to human security. Ever since the break up of the USSR, the populations of the region are constantly affected by a plethora of socio-political and socio-economic problems. Of these issues, lack of good governance, entrenchment of authoritarianism, income disparity, widespread social inequality and systemic corruption are the most common challenges to human security. In contrast to many other postcommunist regions, the end of state communism in the South Caucasus coincided with the outburst of violent separatist conflicts. The Nagorno-Karabakh conflict between Armenia and Azerbaijan, as well as the Georgian-Ossetian and Georgian-Abkhazian conflicts significantly contributed towards other challenges of post-communist transition. In addition, the region also had to cope with the side-effects of a decades-long armed conflict in the neighbouring Russian North Caucasus. Corrupt governments, inefficient economies and the aftershocks of armed conflicts have kept the three South Caucasus's countries at the lower end of most human development, democratic governance and market competitiveness indexes and rankings for the last two decades. Today, the challenges to human security in the South Caucasus region are not significantly different from the immediate post-Soviet period. In Armenia, while the patrimonial ruling elites remain adamantly resistant to change, a stalled transition to a market economy has been accompanied by a democratic reform process that has moved at a glacial pace. In Georgia, political transitions and the modest progress achieved by efforts at democratization are still hindered by economic and political challenges. Over the past ten years, oil-rich Azerbaijan has become further bogged down in authoritarianism.

Of course, lack of democratic governance, weak unstable economies and failures of post-communist transformation efforts are not unique to the South Caucasus. Rather, the majority of non-Baltic former Soviet countries are afflicted by the similar absence of human security, which is characterized both by the lack of 'freedom from fear' and 'freedom from want'. Amongst a diversity of coping mechanisms developed by postSoviet societies to deal with a deficit of good governance and significant economic hardship, reliance on informality-informal inter-personal networks and the 'shadow economy'-is omnipresent; such reliance has been ingrained into the social culture. The 
South Caucasus was not an exception. The tradition of relying on informal networking in Armenia, Azerbaijan and Georgia not only dates back to the pre-Soviet period, but is also entangled in a web of kinship, clan and ancestry, which distinguishes it from the culture of informality in the Eastern European post-communist countries.

This paper seeks to examine the function of informal networks as sources of human (in)security in the post-communist South Caucasus. The key argument is that two decades of human insecurity that followed the end of Soviet rule in South Caucasian republics encouraged the growth of informal networks, well-rooted in the region and has allowed them to perform some of the state's functions. Of these, the role of informal networking is crucial in family support, healthcare, education, employment, community welfare and others functions commonly reserved to the state and civil society. However, apart from such positive roles, these informal networks have also hindered democratic reforms and undermined institution-building by encouraging corruption and clientelism, thereby exacerbating long term human insecurity for the population at large.

Rather than examining the relationship between informal networks and human (in)security in each of the South Caucasus' countries, this article uses the South Caucasus region as a single case study, employing a regional approach. Despite their linguistic, religious and political differences, Armenia, Azerbaijan and Georgia were once part of the same political regime (Soviet Union), they shared similar pre-Soviet history, they also share similar pathways of post-communist transformation and their societies have similar socio-cultural organization. This allows us to study these three countries as a single geopolitical region. While a cross-national analysis may illustrate divergences and convergences in each country, a regional approach will allow us to bridge these differences in order to provide a more generalizable account on how informal institutions affect human (in)security in a post-communist region.

This study relies on qualitative methods of inquiry and is based on empirical findings of 37 in-depth semi-structured elite (expert) interviews conducted by the author in Azerbaijan, Georgia and several major cities of Eastern and Western Europe. Two key categories of informants were interviewed: (1) policy experts and analysts employed at major international and local think-tanks and NGOs, and (2) scholars and researchers at major universities and research centres. The sample selection technique known as 
'snowballing' sampling was based on identifying the key informants from the literature and internet search in accordance with their relevant expertise or work experience. Additional participants were selected by employing 'referral' methods: asking informants to recommend other experts in the field. All interviews were structured as semi-formal discussions during which informants were asked to express their views and opinions and to share their professional experience on association between human (in)security and informal networking in the South Caucasus region.

In addition to expert interviews, this study has drawn its insights from participant ethnographic field observation, which involved observing the function of informal networking in Azerbaijan and Georgia over the period of two decades. Being based in the South Caucasus since the end of communist period, the author has had numerous informal discussions with hundreds of individuals of Azeri, Armenian and Georgian origin on the role of informal networks in the South Caucasus's societies and firsthand observed the organization, structure and workings of such networks.

Analysis of qualitative data is combined here with quantitative survey data borrowed from a number of nation-wide representative surveys conducted in all three republics of the South Caucasus since the break up of the USSR. The bulk of survey data employed throughout this article is taken from a series of surveys conducted by the South Caucasus-based research centre Caucasus Research Resource Centers (CRRC) in Armenia, Azerbaijan and Georgia from 2007 to 2014. Other surveys cited in this study include World Values Surveys (WVS), European Values Surveys (EVS) and surveys by the European Bank for Reconstruction and Development (EBRD) conducted over the past two decades.

\section{Human security and informal networking}

First highlighted by the UNDP's Human Development Report of $1994,{ }^{2}$ the notion of 'human security' has acquired a diversity of definitions over the time. While some scholars have applied the concept of human security in the context of peace and conflict

2 UNDP, 'Human Development Report' (New York: United Nations Development Programme, 1994); Mary Martin and Taylor Owen, 'The second generation of human security: lessons from the UN and EU experience', International Affairs 86, no. 1 (2010): 211-224. 
studies, ${ }^{3}$ anthropology, ${ }^{4}$ international politics, ${ }^{5}$ and environmental issues, others have struggled to bridge definitional gaps arising from a multiplicity of forms. ${ }^{6}$ Indeed, both broad (maximalist) and narrow (minimalist) definitions of human security are abundant in academic literature. ${ }^{7}$ For example, in their comprehensive volume on human security, Alexander and Sabina Lautensach ${ }^{8}$ presented an all-inclusive definition of human security which encompasses political security, economic stability, environmental sustainability and human development. A similar approach to conceptualizing human security has been taken by Picciotto et al., ${ }^{9}$ who suggested combining all definitions of human security into a single paradigm that addresses all issues relevant to human security and development. On the contrary, King and Murray concisely defined human security as 'the number of years of future life spent outside a state of "generalized poverty".' 11

This article understands human security as a balanced combination of two underlying principles: 'freedom from fear' and 'freedom from want'. Human security as 'freedom from fear' not only ensures physical safety of individuals, but also 'meaningful participation in the life of the community, control over one's life and so forth'. ${ }^{12}$ The

\footnotetext{
${ }^{3}$ Earl Conteh-Morgan, 'Peacebuilding and Human Security: A Constructivist Perspective', International Journal of Peace Studies 10, no. 1 (2005): 69-86; David Chandler, 'Resilience and human security: The post-interventionist paradigm', Security Dialogue 43, no. 3 (2012): 213-229; Edward Newman, 'A Human Security Peace-Building Agenda', Third World Quarterly 32, no. 10 (2011): 1737-1756; Mary Kaldor, 'Human Security: Reflections on Globalization and Intervention' (Cambridge: Polity Press, 2007).

4 Thomas Eriksen, Ellen Bal and Oscar Salemink, eds., 'A World of Insecurity. Anthropological Perspectives on Human Security' (London: Pluto Press, 2010).

${ }^{5}$ Matt McDonald, 'Human Security and the Construction of Security', Global Society 16, no. 3 (2002): 277-295; Joseph S. Nye and David A. Welch, 'Understanding Global Conflict and Cooperation: An Introduction to Theory and History' (New York: Longman, 2011).

${ }^{6}$ Jennifer Leaning, 'Psychosocial Well-Being over Time', Security Dialogue 35, no. 3 (2004): 354-355; Robert Picciotto, Michael Clarke and Funmi Olonosakin, 'Global Development and Human Security' (New Brunswick: Transaction Publishers, 2007); Shahrbanou Tadjbakhsh and Anuradha Chenoy, 'Human Security. Concepts and Implications' (London: Routledge, 2007); Mofida Goucha and John Crowley, 'Rethinking Human Security' (Malden: Blackwell Publishing, 2008); Sakiko Fukuda-Parr, 'New Threats to Human Security in the Era of Globalization', Journal of Human Development 4, no. 2 (2003): 167-179; Caroline Thomas, 'Globalization and Human Security', in Globalization, Development and Human Security, ed. Anthony McGrew and Nana K. Poku (Cambridge: Polity Press, 2007), 107-132.

${ }^{7}$ Des Gasper, 'Securing Humanity: Situating 'Human Security' as Concept and Discourse', Journal of Human Development 6, no. 2 (2005): 221-245; Ryerson Christie, 'Critical Voices and Human Security: To Endure, To Engage or To Critique?’ Security Dialogue 41, no. 2 (2010): 169-190.

${ }^{8}$ Alexander Lautensach and Sabina Lautensach, eds., 'Human Security in World Affairs. Problems and Opportunities' (Vienna: Caesar Press, 2013).

${ }^{9}$ Piciotto et al., 'Global Development and Human Security', 34.

${ }^{11}$ Gary King and Christopher Murray, 'Rethinking Human Security', Political Science Quarterly 116, no. 4 (2001): 585-610, 585.

12 Thomas, 'Globalization and Human Security', 109.
} 
'freedom from want', by contrast, prioritizes socio-economic aspects of individuals' life and the provision of basic human needs-employment, welfare, healthcare, food and shelter. ${ }^{13}$ However, these two fundamental principles of human security are not mutually exclusive. In the South Caucasus, and beyond, material insecurity is often intertwined with physical threats.

Having selected informal networks as the unit of analysis, the key priority of this study is human security of individuals, or populations, from socio-economic 'want' and socio-political 'fear'. Such an approach is best encapsulated in a statement by Picciotto et al. ${ }^{14}$ who argue that ' $[\mathrm{h}]$ uman security has to do with the well being of individuals rather than the protection of states'. Yet, human security from 'want' and 'fear' is irrevocably associated with the state and its institutions. ${ }^{15}$ Hence, in this study a bottom-up approach to human security is blended with a focus on institutions, formal and informal alike, as causal factors of insecurity. Accordingly, the question of 'insecurity from whom' not only refers to socio-economic and socio-political hardships emanating from the failures of post-communist transition, but also to insecurity as a by-product of such failures.

In contrast to a voluminous body of academic literature on human security emphasizing the role of international actors in empowering local communities and individuals through development aid, promotion of good governance and a diversity of other exogenous mechanisms, ${ }^{16}$ this paper's primary focus is on endogenous or local coping mechanisms of human security. The most commonly considered endogenous mechanisms of human security are reliance on religion, tradition, culture and identity. ${ }^{17}$ This study adds to this list by examining the functioning of informal inter-personal networks as mechanisms of endogenous human security.

\footnotetext{
13 Jorge Nef, 'Human Security and Mutual Vulnerability: The Global Political Economy of Development and Underdevelopment' (Ottawa: International Development Research Centre, 1999).

${ }^{14}$ Piciotto et al., 'Global Development and Human Security', 32.

15 Tara McCormack, 'Power and agency in the human security framework', Cambridge Review of International Affairs 21, no. 1 (2008): 113-128.

${ }^{16}$ Amitav Acharya, 'Human Security: East versus West', International Journal 56, no. 3 (2001): 442-460; Newman, 'A Human Security Peace-Building Agenda'; Kaldor, 'Human Security'; Piciotto et al., 'Global Development and Human Security'; McGrew and Poku, 'Globalization, Development and Human Security'; Giorgio Shani, Sato Makoto and Mustapha Kamal Pasha, eds., 'Protecting Human Security in a Post 9/11 World Critical and Global Insights' (Basingstoke: Palgrave Macmillan, 2007); Monica den Boer and Jaap de Wilde, eds., 'The Viability of Human Security' (Amsterdam: University of Amsterdam Press, 2008).

${ }^{17}$ Eriksen et al., 'A World of Insecurity'.
} 
This leads towards the next concept-'informal networks'. Informal networks, otherwise described as civic, social, private, interpersonal or personal networks, ${ }^{18}$ are broadly defined by Newman ${ }^{19}$ as 'a set of people or groups of people with some pattern of contacts or interactions between them'. For Rose ${ }^{20}$ informal networks 'are face-to-face relationships between a limited number of individuals who know each other and are bound together by kinship, friendship, or propinquity'. Granovetter, ${ }^{21}$ in his theory on the Strength of Weak Ties, defines all individuals within a society as organized into strong tie networks-groups of people linked to each other by family, kinship or friendship connections. Yet, there has been surprisingly little consideration of informal networks in current human security literature. Far more attention to the role of networks in providing human insecurity has been paid in studies on social capital and informality in the postcommunist context. $\mathrm{Sik}^{22}$ insisted that informal networks were widely employed in Hungary as coping mechanisms in the face of economic crises in the immediate postcommunist period. Rose ${ }^{23}$ has also argued that in Russia, as well as in other 'hour-glass' societies (that is, countries with weak and ineffective governance), informal networks perform both economic and political functions. A similar assumption was also introduced by Ledeneva, ${ }^{24}$ Lomnitz $^{25}$ and Lonkila ${ }^{26}$ in their studies on informal practices in Russia and elsewhere. Informal networks, as coping mechanisms, were also widespread at

\footnotetext{
${ }^{18}$ Gerald M. Easter, 'Personal Networks and Postrevolutionary State Building: Soviet Russia Reexamined', World Politics 48, no. 4 (1996): 551-578.

${ }^{19}$ Mark Newman, 'The Structure and Function of Complex Networks', SIAM Review 45, no. 2 (2003): 167256, 174.

${ }^{20}$ Richard Rose, 'Getting Things Done in Anti-modern Society: Social Capital Networks in Russia', in Social Capital. A Multifaceted Perspective, ed., Partha Dasgupta and Ismail Serageldin (Washington, DC: IBRD, 2000), 147-172, 149.

${ }^{21}$ Mark Granovetter, 'The Strength of Weak Ties', American Journal of Sociology 78, no. 6 (1973): 13601380.

${ }^{22}$ Endre Sik and Barry Wellman, 'Network Capital in Capitalist, Communist, and Post-communist Societies' (Notre Dame, IN: University of Notre Dame Press, 1995).

${ }^{23}$ Richard Rose, 'Russia as an Hour-Glass Society: A Constitution without Citizens', East European Constitutional Review 4: (1995): 34-42.

24 Alena Ledeneva, 'Russia's Economy of Favours: Blat, Networking, and Informal Exchange' (Cambridge: Cambridge University Press, 1998).

${ }^{25}$ Larissa Lomnitz, 'Informal Exchange Networks in Formal Systems: a Theoretical Model', American Anthropologist 90, no. 1 (1988): 42-55.

${ }^{26}$ Markku Lonkila, 'Social Networks in Post-Soviet Russia Continuity and Change in the Everyday Life of St. Petersburg Teachers' (Helsinki: University of Helsinki, 1999).
} 
different periods of modern history in China, ${ }^{27}$ Latin America, ${ }^{28}$ Middle East, ${ }^{29}$ Africa ${ }^{30}$ and other parts of the world. ${ }^{31}$

Although informal networks exist in every society, their function as providers of human (in)security arises only under certain circumstances. In particular, reliance on networks increases when the state fails to fulfil its basic functions and obligations. Tadjbakhsh and Chenoy ${ }^{32}$ explain that '[a] weak state is defined as one that cannot uphold the Hobbesian contract for providing not only security, but also and especially developmental goods and human rights imperatives for its own citizens'. They add that '[i]n weak states, the "freedom from want" perspective is perhaps the most lacking: there is either no or insufficient social protection, welfare systems comparable to those in strong states and health and educational systems are highly incomplete and insufficient'. ${ }^{33}$

If a state is incapable of providing the population with its basic economic needs, this function is usually filled by a networks-operated informal economy. ${ }^{34}$ The rise of informal shadow economies is a particularly well-known phenomenon in centrally planned or command economies, such as the economy of the Soviet Union. ${ }^{35}$ Indeed, the Soviet informal or second economy was notorious for its size and spread. ${ }^{36}$ Throughout Soviet history inter-personal underground networks supplied the population with a range of difficult-to-find goods and services which the embattled command economy of the

\footnotetext{
${ }^{27}$ Yang Mei-hui Mayfair, 'Gifts, Favors \& Banquets: The Art of Social Relationships in China' (London: Cornell University Press, 1994).

${ }^{28}$ Larissa Lomnitz, 'Reciprocity of Favors in the Urban Middle Class of Chile', in Economic Anthropology ed., George Dalton (Washington, DC: American Anthropological Association, 1971); Fernanda Duarte, 'Exploring the interpersonal transaction of the Brazilian jeitinho in bureaucratic contexts', Organization 13, no. 4 (2006): 509-527.

${ }^{29}$ Aseel Al-Ramahi, 'Wasta in Jordan: a distinct feature of (and benefit for) Middle Eastern society', Arab Law Quarterly (2008): 35-62.

${ }^{30}$ Christian M. Rogerson, 'Second economy' versus informal economy: A South African affair', Geoforum 38 (2007): 1053-1057.

${ }^{31}$ Gretchen Helmke and Steven Levitsky, eds., 'Informal institutions and democracy: Lessons from Latin America' (Baltimore: JHU Press, 2006).

${ }^{32}$ Tadjbakhsh and Chenoy, 'Human Security', 173.

${ }^{33}$ Ibid.

${ }^{34}$ Alejandro Portes and Kelly Hoffman, 'Latin American Class Structures: Their Composition and Change during the Neoliberal Era', Latin American Research Review 38, no. 1 (2003): 41-82.

${ }^{35}$ Dennis O'Hearn, 'The Consumer Second Economy: Size and Effects', Soviet Studies 32, no. 2 (1980): 218-234.

${ }^{36}$ Steven L. Sampson, 'The Second Economy of the Soviet Union and Eastern Europe', The ANNALS of the American Academy of Political and Social Science 493, no. 1 (1987): 120-136.
} 
communist state was unable to provide for its citizens. It has been argued that it is because of human insecurity under Soviet rule that informal networks, such as blat networks in Russia, ${ }^{37}$ emerged and became embedded in socio-cultural milieu of socialist societies. Even prior to the incorporation of post-Soviet societies into the Soviet Union, the reliance on informal structures among these societies was traditionally engraved into ethno-cultural traditions and patterns of social organization. However, decades of Soviet socio-cultural standardization blended pre-communist traditions with the typical Soviet way of life and eradicated pre-communist forms of social organization (such as clans and extended patriarchal family in the Caucasus). This massive Soviet socialization has led to the creation of informal traditions endemic to the ex-Soviet region. ${ }^{38}$ For example, as Round and Williams ${ }^{39}$ argued: '[o]f course, such [informal] practices occur the world over; what is different in the post-Soviet context is their importance to everyday life'. This means that the impact of Soviet communism on socio-cultural formation of exSoviet societies, which lasted for almost seven decades, created informal behaviours and traditions distinct and more pervasive than informality elsewhere.

The networks' relationship with human security is not limited to economics. Rose ${ }^{40}$ suggested that ' $[\mathrm{w}]$ hile some capital networks used to produce goods and services in every society, their form is distinctive in an 'anti-modern' society - that is, a society characterized by organizational failure and the corruption of formal organizations'. Weak states are also more often than not governed by undemocratic, autocratic or even dictatorial political regimes. Over the past twenty years, human rights violations, persecution of dissent, political indoctrination and various forms of discrimination became inseparable characteristics of many post-Soviet states. Under such circumstances, the role of informal networks extends beyond their economic functions; they also serve as centres of free expression and as a means of spreading ideas and information beyond the reach of state authorities. Networks of dissidents (informaly) of the perestroika-age Soviet Union are a typical example of networks' role in providing the 'freedom from fear' to the population.

\footnotetext{
${ }^{37}$ Ledeneva, 'Russia's Economy of Favours'.

${ }^{38}$ Rose, 'Getting Things Done in Anti-modern Society', 164.

39 John Round and Colin C. Williams, 'Coping with the social costs of 'transition': Everyday life in postSoviet Russia and Ukraine', European urban and regional studies 17, no. 2 (2010): 183-196, 189.

${ }^{40}$ Rose, 'Getting Things Done in Anti-modern Society', 147.
} 
The growth and proliferation of networks in 'stressful' environments is not only the result of state's weakness, but it is also often a side-effect of both political and social transition. This is best encapsulated in Eriksen et al.'s formulation that 'social insecurity ... arises when societies change quickly. Just as a fish discovers the water only at the moment it is being hauled out of it ${ }^{92}$ such transition-imposed forms of human insecurity are typical to post-Soviet societies. Disappointment with political and economic development and the failure of democratization often results in individuals' higher reliance on networks of family members and friends. For example, the rise of networks in the post-communist Hungary ${ }^{43}$ and Romania ${ }^{44}$ were described as means of coping with transitional insecurity. Contrary to expectations of advocates of transition theories, ${ }^{45}$ both democratization and effective transition to market economy did not occur in the former Soviet Union. There is no doubt that the implementation of neo-liberal policies and generous aid packages provided by Western governments and international organizations have aided in liberalization of markets in the former Soviet Union and assisted in increasing availability of public goods, encouraging improvements in welfare and human security. However, the expectation that post-communist human insecurity would 'only be temporary and that economic growth would bring prosperity to the majority in a short space of time'46 appeared to be far too optimistic. The lack of post-socialist transition, both in politics and economics, and incomplete institutional reforms have led to the continuity of informal behaviours and, as pointed out by Morris and Polese: '[i]nformality is here to stay'. ${ }^{47}$

Although informal networks in weak states perform as social safety nets and provide the population with human security, they may also have a dark side. In weak states, such networks often contribute to, if not overtly create, human insecurity in a

\footnotetext{
${ }^{42}$ Eriksen et al., 'A World of Insecurity', 14.

${ }^{43}$ Sik and Wellman, 'Network Capital'.

${ }^{44}$ Byung-Yeon Kim, 'Poverty and informal economy participation. Evidence from Romania', Economics of Transition 13, no.1 (2005): 163-185.

${ }^{45}$ Michael McFaul, 'The Fourth Wave of Democracy and Dictatorship: Noncooperative Transitions in the Postcommunist World', World Politics 54, no. 2 (2002): 212-244; Valerie Bunce, 'Rethinking Recent Democratization: Lessons from the Postcommunist Experience', World Politics 55, no. 2 (2003): 167-192.

${ }^{46}$ Colin C. Williams, John Round and Peter Rodgers, 'The Role of Informal Economies in the Post-Soviet World' (Hoboken: Taylor and Francis, 2013), 21.

47 Jeremy Morris and Abel Polese, eds., 'The Informal Post-Socialist Economy. Embedded Practices and Livelihoods' (Oxon: Routledge, 2014), 1.
} 
diversity of ways. Firstly, the existence of a shadow economy is a heavy burden for formal economies; they not only divert labour force from formal activities, but also by altering incentive structures and economic tradeoffs can disorganize and hamper the performance of the formal economy. Informal economic activities also deprive governments of tax revenue and reduce state investment capacity. Informal practices, such as the notorious Soviet-Russian practice of blat, prioritize reciprocity of favours and informal exchanges over formal rules and regulations. Secondly, reliance on networks in politics reduces the legitimacy of formal institutions and erodes democratic processes. In both economics and politics, informal networks enhance clientelism and corruption, destabilizing and crippling state structures. As a consequence the relationship between a weak state and informal networking is multifaceted. If human insecurity, increasing as a result of state weaknesses, leads to strengthening of networks, the growth of networks results in further decomposition of state authority.

\section{Dimensions of human insecurity in the South Caucasus}

Along with the devastating effects of separatist conflicts, present-day human insecurity in the South Caucasus stems from the weakness of state institutions and the detrimental impact such institutions have upon populations they attempt to govern. For over two decades after the collapse of the USSR, the pace of political transition in the region has been painstakingly slow. Only in Georgia has the pro-Western government of Mikheil Saakashvili succeeded in implementing a series of legislative, judicial and administrative reforms. As a result, Georgia's ranking in the Corruption Perception Index reached 51st place in 2012, as compared to 133 rd place in $2004 .{ }^{48}$ Democratic reforms in Georgia have also resulted in improvements of state institutions. Freedom House, for example, has upgraded Georgia to the category of transitional or hybrid regimes with semi-democratic institutions and notable institutional improvements over the past ten years. ${ }^{49}$ Georgia's

\footnotetext{
48 Transparency International, 'Corruption Perceptions Index', http://www.transparency.org/research/cpi/overview (accessed December 20, 2014).

49 Christopher Walker and Sylvana Habdank-Kołaczkowska, 'Nations in Transit. Fragile Frontier: Democracy's Growing Vulnerability in Central and Southeastern Europe' (Washington DC: Freedom House, 2013).
} 
political transformation is still very fragile, however. The failure to consolidate democratic reforms and resolve Georgia's territorial conflicts continues to polarize the society and threaten the political stability of the country.

In Armenia, the process of institution-building remains stalled and as of 2013, according to the Nations in Transit project, has been in continuous decline since 2002. ${ }^{50}$ Described as a semi-consolidated authoritarian state, Armenia has witnessed a controlled succession of leaders from Robert Kocharyan, who held the executive's office for ten years, to his hand-picked successor, Serzh Sarkisyan. During the last decade, no positive developments took place in Armenia's electoral transparency and judicial framework. Widespread human rights violations, occasionally eased by government's attempts to create failed dialogues with the political opposition, have continued over the same period. Furthermore, rampant corruption in Armenia continuously keeps the country at the bottom end of international corruption rankings.

However, the failure of political transition is far more obvious in Azerbaijan than in neighbouring Armenia and Georgia. For the past twenty years, Azerbaijan, which has had no transition of ruling elites since the early 1990s, has been steadily descending towards consolidated authoritarianism. Declining human rights records, persecution of independent press and almost complete failure of democratization has come hand in hand with a further entrenchment of ruling elites, limitless presidential terms and flawed elections. The Freedom of the World report of 2014 presents the decline of political rights and civil liberties in Azerbaijan since 2003 as amongst the worst in the former Soviet Union. ${ }^{51}$

Throughout the 1990s, all three newly independent states of the South Caucasus were equally overwhelmed by economic crises. Their industries, dependent on raw materials from other parts of the USSR, were stalled on the verge of collapse. In the 1990s, the gross domestic products of Armenia, Azerbaijan and Georgia were equally low. While in the immediate post-communist period Armenian GDP was the lowest amongst its neighbours in the South Caucasus, the gross domestic products of Azerbaijan

\footnotetext{
${ }^{50}$ Ibid.

${ }^{51}$ Freedom House, 'Freedom in the World 2014' (Washington DC: Freedom House, 2014).
} 
and Georgia were fairly similar. ${ }^{52}$ Not only was the economic and industrial performance of the Caucasus's republics stagnant but overall living standards-in education, healthcare, social and human security-were also in a state of decline. After surviving the harsh economic recession of the 1990s, the South Caucasus's republics have embarked on a period of steady economic growth. In the decade from 2001 to 2011, the gross domestic products of Armenia and Georgia more than tripled while Azerbaijan's GDP growth placed the country on the list of the world's fastest growing economies in 2010.

Nevertheless, such official economic development data fails to capture the actual socio-economic situation. Rampant unemployment, low living standards, lack of access to healthcare and social welfare, as well as a multitude of other socio-economic problems in all three South Caucasus's countries often remain neglected and ignored by the authorities. For instance, according to a Caucasus Barometer survey carried out by the Caucasus Research Resource Centres (CRRC) in 2013, over 56\% of respondents across Armenia were unemployed; these figures stand at 59\% in Azerbaijan and 60\% in Georgia. ${ }^{53}$ By contrast, the official rate of unemployment in Armenia was registered as seven per cent (2012), in Azerbaijan at one per cent (2012) and in Georgia at 15\% (2011). While poverty is not widespread in the region, low incomes and difficulty of finding decent jobs continue to be a challenge for the majority of population. As reported by the Caucasus Barometer survey, monthly incomes of the majority of respondents in three South Caucasus's republics were ranging from US\$200 to US\$300. Only eleven per cent of public in Armenia and Azerbaijan, and seven per cent in Georgia described their economic condition as good.

This brief overview of the socio-political and socio-economic environment in the South Caucasus suggests that both the 'freedom from fear' and 'freedom from want' remain equally important for the vast majority of population. Political oppression and economic instability are long-term phenomena in the South Caucasus. Regardless of increases in countries' gross domestic products, socio-economic hardships remain chronically unaddressed. Although the Georgian example presents a deviation from this

\footnotetext{
${ }^{52}$ In 1993 GDP of Armenia (in current US dollars) was USD \$356, Azerbaijan’s GDP was USD \$530 and Georgia's USD $\$ 550$.

${ }^{53}$ CRRC, 'Caucasus Barometer, 2013' (Tbilisi: Caucasus Research Resource Centers (CRRC), 2013).
} 
pattern, South Caucasus governments are usually unwilling to tackle socio-political and socio-economic problems in their respective countries.

The weaknesses of institutions and governments in the South Caucasus have been widely investigated in the literature and need not to be discussed in detail for the purpose of this study. ${ }^{54}$ Of particular importance for this paper, however, is that these weaknesses generally occur owing to the unwillingness or failure of political actors to facilitate transformation, implement reforms and to strengthen institutions. For instance, Tadjbakhsh and Chenoy ${ }^{55}$ distinguish between two types of weak political regimes: unwilling and incapable states. Human insecurity in an incapable state is a result of structural obstacles, such as natural disasters, geo-political location, and globalization, which incapacitates governments. In an unwilling state, human insecurity emanates from the lack of will on the part of governments to provide their citizens with physical and social security. According to Tadjbakhsh and Chenoy, ' $[\mathrm{t}]$ he unwilling state is one where people fear official security forces, the state and the police, where corruption is rampant and riches are not distributed intentionally, and where dictatorships prefer to strengthen their own subsistence. ${ }^{56}$ Although neither Armenia nor Georgia can be described as a 'dictatorship', serious institutional flaws, in conjunction with continuous failures of policy-makers and their lack of willingness to address human insecurity in a consistent manner illustrate the unwillingness, rather than the lack of capacity of these states.

While international assistance, humanitarian aid and even intervention, are often recommended as a remedy for incapable states, apart from policy recommendations, not much is suggested in the literature on human security for unwilling states. Yet, solutions to alleviate human insecurity in unwilling states often emerge from the bottom-up in form of coping mechanisms. These coping strategies are usually created by the affected population. The bottom-up mechanisms of dealing with the state weakness range from revolutions and uprisings to long-term adaptation strategies. Although the contemporary history of the South Caucasus is rife with examples of regime changes and revolts against governments, the political transformations more often than not have proven incapable of

\footnotetext{
54 Armine Ishkanian, 'Democracy Building and Civil Society in post-Soviet Armenia' (New York: Routledge, 2008).

55 Tadjbakhsh and Chenoy, 'Human Security', 172.

56 Ibid.
} 
significantly transforming the continuity of elites and the engraved into socio-political culture traditions. In contrast, reliance on long-term mechanisms of social adaptation became a time-tested reliable method of safeguarding human security. Perhaps the most widespread, albeit often neglected by the literature, coping mechanism of the affected by human insecurity South Caucasus's societies is the reliance on informal networks.

\section{Networks as sources of post-communist security}

A number of socio-political and socio-economic developments of the immediate postSoviet period predetermined the survival of widespread informal networking under communism and its proliferation. Although the communist state no longer existed, its machinery of control and indoctrination were preserved by the political regimes succeeding the Soviet Union in the South Caucasus. Short-lived expectations of transition to democracy and market economy have turned into disillusionment with failures of nationalist dissident-led governments of Levon Ter-Petrosyan in Armenia, Abulfaz Elchibey in Azerbaijan and Zviad Gamsakhurdia in Georgia. All three newly independent South Caucasus countries were also severely hit by the economic crisis of the 1990s. By 1995, the gross domestic products of Armenia, Azerbaijan and Georgia dropped by over $40 \%$. The 'transition decline' affected governments' spending on healthcare, education, social welfare and most other public services. Violent separatist conflicts, which started ravaging the region even before the end of the USSR, further derailed economic transformation, dispatching waves of internally displaced persons (IDPs) all across the region and leaving in ruins the entire territories of Abkhazia, South Ossetia, NagornoKarabakh and adjacent to conflict-affected areas regions of Azerbaijan and Georgia.

As a consequence, reliance on networks throughout the turbulent 1990s became even more vital than under the Soviet rule. Kinship-centred informal networks remained widespread in the post-Soviet South Caucasus. The World Values Survey (WVS) administered in the mid 1990s reported that the majority of the population in Armenia (86\%), Azerbaijan (85\%) and Georgia (94\%) believed that family plays a very important 
part in their lives. ${ }^{57}$ This data markedly contrasts to responses to the WVS in other postSoviet countries: only $68 \%$ of public in Lithuania, $70 \%$ in Latvia and $79 \%$ in Moldova said that family ties are very important. The WVS survey also illustrated that over $60 \%$ of people in the South Caucasus were dissatisfied with their financial situation in the mid 1990s. ${ }^{58}$ This shows that as new governments were too weak to provide their citizens with basic human needs, informal networks remained in high demand throughout the immediate post-communist period.

While 'freedom from want' only increased during the first post-communist decade, 'freedom from fear' also began to acquire a different shape. The relative political liberty under the brief and chaotic period of nationalist government in the South Caucasus ended with the return of 'old school' communist-era elites. Robert Kocharyan in Armenia, Heydar Aliev in Azerbaijan and Eduard Shevardnadze in Georgia took over presidential offices in their respective republics. All were well-trained, experienced and wellconnected through intricate webs of informal networks developed during their service in Soviet administrations. By 1997—with the exception of Azerbaijan where $92 \%$ of public expressed trust in their government- $58 \%$ of population in Armenia and close to 50\% in Georgia mistrusted the leadership of their republics. ${ }^{59}$ Yet even in Azerbaijan, 94\% of public believed that having a political system controlled by a strong leader is not good. ${ }^{60}$ Entrenchment of authoritarianism and steady, albeit implicit, persecution of regime opponents began to increase by the late 1990s.

\section{Structure of post-communist informal networks}

What is the structure and composition of present-day informal networks in the South Caucasus? Traditional reliance on family and relatives defines the nature of networks in the region; strong 'bonding' within a network and weak 'bridging' between networks is a typical characteristic of the South Caucasus's informal networks. In the words of an expert, 'strong intra-network bonding of social capital is what Georgians and other ethnic

\footnotetext{
${ }^{57}$ WVS, ‘WVS 1990-1994, WVS 1995-1998’ (Lueneburg: World Values Surveys).

${ }^{58}$ Ibid.

${ }^{59}$ Ibid.

${ }^{60}$ Ibid.
} 
groups of the South Caucasus have inherited from the Soviet period' ${ }^{61}$ The distribution of public goods within such networks is usually based on blood lineage and the proximity of kinship ties. Reciprocity of favours amongst family and kin members is often not an obligation; instead it is subject to hierarchy and seniority within a network based on age and status.

A typical kinship network in the South Caucasus is staunchly homogenous and exclusivist. This means that new members can only enter the 'circle of trust' through birth or marriage. Each member of a kinship network is also likely to have a circle of close trusted friends, which serve as 'weak ties' connecting strong tie kinship groups. An expert on Georgian society explained 'that while kinship networks are still prominent in rural areas, the most widespread type of networks in urban settlements is friendship groups. ${ }^{62}$ In Azerbaijan, as mentioned by a local expert, 'kinship and friendship networks are equally important in urban areas. However, kinship groups undoubtedly dominate the social landscape of rural settlements. ${ }^{, 63}$

However, in spite of the importance of friendship ties for the majority of population; ${ }^{64}$ the distribution of public goods in friendship networks is never equal to the exchange of goods and services within kinship groups. As Misztal ${ }^{65}$ wrote about communist-era informal networks, '[b]eing part of an informal circle was seen as the main way of achieving some level of social, financial and psychological security'. Hence, outsiders, including not-so-well-known friends, are generally treated with a degree of suspicion and will only be allowed into one's friendship circle after the necessary period of 'bonding'. For instance, an opening for a lucrative job will only be offered to a friend if no family or kin members are available to accept it. ${ }^{66}$ However, favours of lesser importance, such as references needed to receive a preferential treatment in different state and non-state institutions, are often eagerly distributed to friends and even acquaintances with an expectation of reciprocity.

\footnotetext{
${ }^{61}$ Interview at the CRRC, Tbilisi, September 2013.

${ }^{62}$ Interview with Professor, Ilia State University, Tbilisi, September 2013.

${ }^{63}$ Interview with Professor, Baku State University, Baku, August 2013.

${ }^{64}$ Leslie Hough, 'Social Capital in Georgia', Caucasus Analytical Digest 31 (2011): 2-5.

${ }^{65}$ Barbara Misztal, 'Informality: Social Theory and Contemporary Practice' (New York: Routledge, 2002), 215.

${ }^{66}$ Interview at FRIDE, Brussels, July 2013.
} 
Owing to the limitations of one's kinship network in providing all necessary public goods, the maintenance of weak ties, or friendship and acquaintance networks is essential for one's personal wellbeing. Unlike informal networks in Russia and other Eastern European countries, ${ }^{67}$ where reciprocal favours are distributed equally amongst friends and family members, South Caucasus's informal structures continue prioritizing kinship groups over friendship networks. ${ }^{68}$ Such characteristic is both a legacy of the Soviet period, when the survival of traditional families was seen as one of the main goals of networking, and is a means of ensuring that the maximum amount of public goods is distributed amongst the members of kin groups.

\section{'Freedom from want'}

On surviving harsh economic recession of the 1990s, the economies of Armenia, Georgia and, particularly, Azerbaijan embarked on a process of recovery and growth. By 2006, the GDP of all three South Caucasus' countries more than doubled. The improvement in living standards has led to a reduction in reliance on informal networks as sources for procuring food items and other day-to-day goods; the networks' function in providing basic material needs of population eventually became obsolete. Notwithstanding the availability of consumer goods, however, jobs remain scarce. Healthcare, education, welfare, as well as most other public services, were underdeveloped and ignored by postSoviet governments. As a consequence, despite the improved living conditions, kinship networks have continued to dominate the informal sphere of the South Caucasus during the 2000s. According to the European Values Survey, ${ }^{69}$ over $90 \%$ of respondents in Armenia and Georgia and over $80 \%$ in Azerbaijan believed that family connections play a very important role in their daily lives. As explained by several experts, the role of informal networking in welfare provision in the second post-communist decade remained as essential as during the 1990 s. $^{70}$

\footnotetext{
${ }^{67}$ Ledeneva, 'Russia's Economy of Favours'.

${ }^{68}$ Huseyn Aliyev, 'Post-Communist Informal Networking: Blat in the South Caucasus', Demokratizatsiya: The Journal of Post-Soviet Democratization 21, no. 1 (2013): 89-112; Huseyn Aliyev, 'Civil Society in the South Caucasus: Kinship Networks as Obstacles to Civil Participation', Journal of Southeast European and Black Sea Studies 14, no. 2 (2014): 263-282.

${ }^{69}$ EVS, 'EVS 2008 - 4th wave', (Tilburg: European Values Study, 2008).

${ }^{70}$ Interviews at CIPDD, Tbilisi and APRODEV, Brussels, July- September 2013.
} 
No longer used to procure basic consumer goods, informal networks are now employed to obtain scarce public goods—-such as jobs, financial loans, insurance, as well as access to healthcare, education and preferential treatment by state officials. The Caucasus Barometer survey, ${ }^{71}$ administered in all three South Caucasus's republics throughout 2011, revealed that over $30 \%$ of the public believed that connections are very important in finding a good job. A significant number (over 30\%) of respondents also mentioned that they did paid or unpaid work for their family members. The role of networks in distribution of good jobs is not only determined by the lack of decent employment opportunities, but also by the low level of social trust. ${ }^{72}$ For the majority of employers hiring a family member, relative or a close friend offers a better guarantee of an employee's qualities than a good reference letter and is also an opportunity for intranetwork bonding. ${ }^{73}$ In the words of an expert:

Giving a job to a stranger, even if that person has positive references, is both risky and irrational. There is no guarantee that this person won't steal or won't let you down. It is much safer to hire a relative, or a good friend; they will be grateful to you for giving them the job and trust relations [built over time] ... or family obligations will serve as a guarantee of their performance. $^{74}$

Network connections are also essential in securing such public goods as higher quality healthcare, access to services offered by state institutions, admissions to better universities and schools, as well as various other public services unavailable or hard-toaccess without proper connections.

Informal networks are important for the socio-economic human security of the South Caucasus's population also because of relatively low household incomes in the

\footnotetext{
${ }^{71}$ CRRC, 'An Assessment of Social Capital in Georgia' (Tbilisi: Caucasus Research Resource Centers, 2011).

${ }^{72}$ Only $27 \%$ of respondents to the Caucasus Barometer 2013 survey in Azerbaijan believed that most people can be trusted. In Armenia, the level of social trust was even lower: 15\% of survey participants. And in Georgia $30 \%$ of the public had trust in people.

${ }^{73}$ Interview at CRRC, Tbilisi, September 2013.

${ }^{74}$ Interview at ISET, Tbilisi, September 2013.
} 
region. For example, the 2013 Caucasus Barometer survey ${ }^{75}$ found that the majority of respondents in Armenia, Azerbaijan and Georgia described their monthly income as below US\$300. At the same time over $80 \%$ of survey participants in Armenia and Georgia and over $90 \%$ in Azerbaijan said that the lowest monthly income should be above US $\$ 400$. Notwithstanding relatively low official poverty data, ${ }^{76}$ actual poverty level is fairly high in all three republics. For instance, contrary to official figures, $50 \%$ of Caucasus Barometer's respondents in Georgia, 57\% in Azerbaijan and 55\% in Armenia described their current economic rung as lowest in the country. A study by the European Bank for Reconstruction and Development ${ }^{77}$ shows that during the global financial crisis of 2008-10, the South Caucasus's households had the highest amongst all other postcommunist regions use of private safety nets and the lowest reliance on public safety nets.

Most households in the South Caucasus also lack financial security. According to the Caucasus Barometer survey, ${ }^{78} 88 \%$ of the public in Armenia, $82 \%$ in Azerbaijan and $89 \%$ in Georgia had no personal savings. Similarly, over $60 \%$ of respondents in Armenia, $60 \%$ in Azerbaijan and over $40 \%$ in Georgia did not have bank accounts. Hence, reliance on networks for loans and financial support in moments of need becomes the only available source of material assistance for the majority of people. The survey's results also emphasized that almost half of the region's population have personal debts and 59\% of people in Georgia, 52\% in Armenia and 53\% in Azerbaijan mentioned that they regularly borrow money for food. Over $60 \%$ of the public in Azerbaijan and over $40 \%$ in Armenia and Georgia also said that their ability to borrow money outside of the household is very limited. As echoed by an expert in Georgia:

It is an unwritten rule that to borrow some money you need to approach only the well-trusted members of your network-usually close relatives.

\footnotetext{
75 CRRC, 'Caucasus Barometer, 2013'.

${ }^{76}$ According to the World Bank, the poverty headcount ratio at national poverty line in Armenia is $35.8 \%$ (2010), in Azerbaijan is 15.8\% (2008) and 24.7\% (2009) in Georgia.

77 EBRD, 'Life in Transition. After the Crisis' (London: European Bank for Reconstruction and Development, 2011), 10.

${ }^{78}$ CRRC, 'Caucasus Barometer, 2013'.
} 
They know that you have to return money and they will not ask for the interest. Also, unlike banks, they won't pressure you [to payback]. ${ }^{79}$

Informal networks also serve as social safety nets offering assistance to their members in emergencies. For instance, almost $90 \%$ of the public in Armenia and Azerbaijan and over $80 \%$ in Georgia in responding to a question by the Caucasus Barometer survey on who provided them assistance in moments of emergency indicated their families and relatives. Similar data is presented by the 'Volunteerism and Civic Participation survey, conducted by the CRRC in Georgia; ${ }^{80}$ the plurality of respondents stated that they do not have car insurance and in case of damages in car accidents they would borrow money from family or relatives.

This analysis of recent data highlights how informal networks in present-day Armenia, Azerbaijan and Georgia perform essential socio-economic functions. Most importantly, the absence or deficiency of basic public services and the lack of public safety nets provided by the state to ensure the socio-economic security of its citizens enhance the networks' function as providers of human security in areas and sectors traditionally reserved to the state and non-state formal institutions, such as public agencies, banks, companies, NGOs and other formal institutions. Although the importance of networks in safeguarding socio-economic safety nets stems from the weakness of formal institutions, this reliance on informality further weakens formal structures and deprives them of credibility. ${ }^{81}$ In Armenia and Georgia less than half of the population trusts banks and in Azerbaijan the level of trust towards formal financial institutions is below $50 \%{ }^{82}$ Respondents expressed similarly low levels of trust towards healthcare and educational systems. In Georgia less than 50\% of respondents expressed their trust in the public healthcare system, in Armenia 42\% and in Azerbaijan 50\%. ${ }^{83}$

\footnotetext{
${ }^{79}$ Interview at ISET, Tbilisi, September 2013.

${ }^{80}$ CRRC, 'Volunteerism and civic participation 2011 survey in Georgia' (Tbilisi: Caucasus Research Resource Centers (CRRC), 2011).

${ }^{81}$ Interviews at several NGOs in Tbilisi and Baku, August-September 2013.

${ }^{82}$ CRRC, 'Caucasus Barometer, 2013'.

${ }^{83}$ Ibid.
} 


\section{'Freedom from fear'}

Unlike economic growth, political developments of the last decade offered little hope for the improvement of human security in socio-political areas. Only in Georgia did a range of democratic reforms in the aftermath of the 2003 'Rose Revolution' spearhead some political change, including the notable transformations of legislative, judicial and even the executive branch. A vigorous anti-corruption campaign under Mikheil Saakashvili's administration virtually eliminated small-scale corruption in Georgia. Although the achievements of the Georgian 'Rose Revolution' were partly marred by Saakashvili's failure to resolve problems with ethnic minorities, in conjunction with the bitter territorial conflict with Russia over South Ossetia, decentralization and liberation of the political regime resulted in the improvement of political and civil liberties. In contrast, there was little positive development in areas of political transformation in Armenia and particularly in Azerbaijan. Instead, the entrenchment of authoritarianism in Azerbaijan and the lack of political succession in Armenia increased the function of informal networking in safeguarding civil and human rights of the people. As lamented by an expert, in Azerbaijan 'because nobody trusts corrupt state authorities, people prefer to solve problems through networks. ${ }^{84}$

However, rather than resulting in the rise of dissident politicized 'underground' networks, similar to the perestroika-age Soviet Caucasus, political oppression in presentday South Caucasus leads to further distancing of informal networks from politics. In the words of a political expert: 'in Armenia and Azerbaijan lots of people are losing any interest of participating in politics, not even discussing politics. ${ }^{, 85}$ For example, the Caucasus Barometer surveys of 2011-12 revealed that the majority of its respondents$70 \%$ in Azerbaijan and 67\% in Georgia-never discuss politics with their family and kin members. Alternatively, 68\% of public in Azerbaijan and 69\% in Georgia also never discuss politics with their friends ${ }^{86}$ Although political protests are frequent occurrences across the region, rather than challenging regimes, the populations of autocratic Azerbaijan and Armenia further retreat into the private sphere. According to the

\footnotetext{
${ }^{84}$ Interview at EPC, Brussels, June 2013.

${ }^{85}$ Interview at APRODEV, Brussels, July 2013.

${ }^{86}$ CRRC, 'Caucasus Barometer' (Tbilisi: Caucasus Research Resource Centers (CRRC), 2012).
} 
Caucasus Barometer survey of 2011 ${ }^{87}$ approximately half of respondents in Azerbaijan and Armenia thought that bringing a case to the court will make the problem worse. In comparison, only $22 \%$ of respondents in Georgia believed that applying to a court will make things worse. In 2013, over $80 \%$ of respondents in Armenia and around half of survey participants in Azerbaijan also believed that people are not treated fairly by the government. In Georgia, only $41 \%$ of the public thought that the government is unfair. ${ }^{88}$ The apolitical nature of informal networks in the South Caucasus results not only in the separation of politics from socio-economic functions of networks but also in the decline of trust towards formal institutions. The levels of trust towards state institutions in Armenia and Azerbaijan are dramatically low. ${ }^{89}$

Participation in formal civil society organizations is even lower. As reported by the EVS of 2008 and the Caucasus Barometer survey of 2011, less than four per cent of respondents in all three South Caucasus's republics were members or participants of civil society groups. In the words of a researcher in Georgia, 'people are reluctant to engage in collective action or to join NGOs because informal networks provide all the social capital that they may need ${ }^{90}$ Another expert echoes this opinion by adding that:

It is due to this deeply entrenched in the South Caucasus's distrust to institutions and individuals, people prefer to do everything within their kinship and friendship circles, rather than dealing with formal institutions - be it a state institution or a non-governmental organizationboth are equally mistrusted and perceived as useless by the population. ${ }^{91}$

As a consequence similarly to the populations' response to socio-economic problems, the lack of efficient and transparent governance is met by higher reliance on informality and further erosion of trust towards the institutions.

\footnotetext{
87 Ibid.

${ }^{88}$ CRRC, 'Caucasus Barometer, 2013'.

${ }^{89}$ According to the Caucasus Barometer's survey in 2013, less than $30 \%$ of public across the region trust local governments, less than $20 \%$ trust court systems and mass media.

${ }^{90}$ Interview at CRRC, Tbilisi, September 2013.

${ }^{91}$ Interview at APRODEV, Brussels, July 2013.
} 


\section{The networks' contribution to human insecurity}

Previous sections have demonstrated that the post-Soviet informal networks continue serving as primary sources of human security in socio-economic and socio-political areas across the South Caucasus. However, it is difficult to describe the informal structures as efficient bottom-up mechanisms offering human security to populations facing failures of governance and/or economic difficulties. As argued by Misztal ${ }^{92}$ the growth of informal networks and popular reliance on them for human security in the communist and postcommunist Eastern Europe reinforced two particularly detrimental factors for institutionbuilding phenomena: clientelism and corruption. The South Caucasus is not an exception.

Patron-client relations, employed by the networks as means of preserving hierarchy between different networks and amongst members of the same network, penetrate all areas of public and private life in the South Caucasus. The principles of patronage and clientelism are often intertwined with traditional respect for older, more experienced and powerful individuals, who are more likely to occupy leading positions in networks and formal institutions. Accordingly, age and experience serve as indicators of each individual's number of inter-personal connections and therefore define the person's place in a network. According to an expert in Azerbaijan:

Elder members of informal structures tend to both patronize and control others. As a result, everything [favours] is distributed in a top-down manner. This holds true not only for kinship and friendship networks, but also for informal networks functioning within institutions. Within such structures you can only get promoted to the top if you belong to a particular patrilinearly-defined family or clan and you are also an 'aksakkal' [elder]. A similar principle works for distribution of official positions in state institutions. ${ }^{93}$

\footnotetext{
92 Misztal, 'Informality', 207, 215.

93 Interviews with NGOs’ staff in Baku, August-September 2013.
} 
Because of the prevalence of patron-client relations and the need to maintain hierarchy, informal networks in the South Caucasus remain staunchly homogenous and exclusivist. This means that the distribution of public goods is very unequal within and between networks. Owing to their closed and segregationist nature, networks only succeed in offering human security to members of their own kin groups and, in a lesser degree, to close friends. Accordingly, human security—as a public good—provided by informal networks in the South Caucasus significantly differs from the protection offered to the population by formal institutions in the Western welfare countries. The bulk of public goods amassed by a number of powerful networks, rather than being distributed amongst the population on an equalitarian basis, remains 'locked' within these networks. ${ }^{94}$

The relationship between informal networks and corruption is twofold. On the one hand, bribes, often in a form of material gifts, are usually used as means of reciprocity to third-party individuals or non-network members. Since the exchange of goods and services through weak ties, connecting members of a particular network to their acquaintances and not-so-close friends, cannot often be reciprocated with favours, some transactions require a 'one-time' sign of gratitude. As explained by an expert:

Offering a gift in exchange for a service to someone who was recommended to you by a friend or a relative is not usually seen as bribery, but as a sign of gratitude to that individual and as a token of respect to a member of your circle who served as an intermediary. It is a social obligation. ${ }^{95}$

On the other hand, corruption is seen as a mechanism of dealing with formal institutions. Paying bribes to officials not only ensures faster and more efficient service, but also de-formalizes state institutions by incorporating them into networks. For instance:

\footnotetext{
${ }^{94}$ Interview at Ilia State University, Tbilisi, September 2013.

95 Interview at Baku State University, August 2013.
} 
Across the South Caucasus, similarly to many other post-Soviet countries, people prefer to build up a sort of trust-based relations with officials at institutions by regularly offering them monetary and other material gifts. This allows people to both receive preferential treatment and to expand their friendship networks heavily investing into these 'mutuallyfavourable' relations. ${ }^{96}$

For the past two decades, the Transparency International Corruption Perceptions Index regularly placed Armenia, Azerbaijan and Georgia into the ranks of the most corrupt countries of the world. The post-'Rose Revolution' reforms in Georgia reduced low-level corruption in the country. However, as pointed out by a local expert in Georgia:

It is true that corruption has been eradicated on the lower levels of governmental bureaucracy. For instance, if you want to extend your passport or receive a land register you no longer have to pay a bribe. Yet, now it [corruption] switched to higher levels and it is more of an issue of politics. $^{97}$

Borzel and Pamuk ${ }^{98}$ (2011) confirm that Georgia's fight against corruption has done little to eradicate corruption amongst elites. Whereas Georgia's fight against corruption has been effective at tackling the issue of corruption at lower levels of administration, the 2011-12 anti-corruption campaigns in Armenia and Azerbaijan are seen by experts as failures. ${ }^{99}$

\section{Conclusion}

\footnotetext{
${ }^{96}$ Interview at EPI, Brussels, June 2013.

${ }^{97}$ Interview at CRRC, Tbilisi, September 2013.

98 Tanja Börzel and Yasemin Pamuk, 'Pathologies of Europeanization Fighting Corruption in the Southern Caucasus', West European Politics 35, no. 1 (2011): 79-97.

${ }^{99}$ Interviews at European Commission, Brussels, July 2013.
} 
For decades economic hardships and deficiencies of political and administrative governance compelled the population of the South Caucasus to rely on informal structures for basic human security. Despite economic and political transformations of the post-communist period, the underlying causes of human insecurity-unequal distribution of wealth, lack of social safety nets and a deficit of democratic governance-remain unresolved. All of the above is further exacerbated by the inherent weakness of formal institutions and their inability to provide the population with such public goods as jobs, decent and affordable healthcare, education and social welfare. As a consequence, informal coping mechanisms continue serving as well-trusted and reliable sources of human security in the South Caucasus. Unlike the informal structures in the Eastern European former communist regions, the South Caucasus's networks are very homogenous, exclusionist and kinship-centred. These characteristics allowed these networks to preserve traditions and culture and provide their members with material and public goods in times of scarcity. However, the lack of inter-network bridging, combined with high levels of intra-network bonding, leads to unequal distribution of public goods and a proliferation of clientelism and corruption. One of the more significant findings to emerge from this study is that the informal networks proliferate when no other effective mechanisms of human security are available to the population. When there is no sufficient 'freedom from want' and 'freedom from need', networks assume both positive and negative functions. It must then follow that the continuous commitment to democratic reforms, institution-building and the creation of social safety nets is needed to reduce not the reliance on networks as sources of human security but the networks' reliance on processes which are detrimental to human security principles. 